\title{
ІНФОРМАЦІЙНА, ВЕБ-, МОБІЛЬНО-ОРІЄНТОВАНА СИСТЕМА В ПРАКТИЦІ СІМЕЙНОГО ЛІКАРЯ
}

О. В. Кутакова

Національна медична академія післядипломної освіти імені П. Л. Шупика

\begin{abstract}
Стрімка інформатизація всіх сорер життя ставить виклики до впровадження інформаційних технологій у галузі охорони здоров'я. Проведено структуризацію діяльності сімейного лікаря для подальшої реалізації веб-, мобільноорієнтованої інооомаційної системи в практиці сімейного лікаря, що є важливим кроком для розвитку даного напряму галузі. Адже саме це допоможе структурувати роботу лікаря, підтримати його в прийнятті рішень та надати можливість для безперервного профресійного розвитку.
\end{abstract}

Ключові слова: сімейна медицина, інформаційна система, алгоритм, мобільно орієнтоване середовище.

\section{INFORMATION, WEB, MOBILE-ORIENTED SYSTEM IN THE PRACTICE OF THE FAMILY DOCTOR}

O. V. Kutakova

\section{Shupyk National Medical Academy of Postgraduate Education}

\begin{abstract}
Rapid informatization of all life spheres poses challenges to the information technology introduction in the medical sector. The structuring of the family doctor's activities for further implementation of the web, mobile oriented information system in the practice of the family doctor is an important step for the development of this field of medicine. After all, this will help to structure the work of the doctor, support him in making decisions and give them the opportunity for continuous professional development.
\end{abstract}

Key words: family medicine, information system, algorithm, mobile-oriented environment.

\section{ИНФОРМАЦИОННАЯ, ВЕБ-, МОБИЛЬНО-ОРИЕНТИРОВАННАЯ СИСТЕМА В ПРАКТИКЕ СЕМЕЙНОГО ВРАЧА}

О. В. Кутакова

Национальная медицинская академия последипломного образования имени П. Л. Шупика

Стремительная инфрорматизация всех сфер жизни ставит вызовы к внедрению информационных технологий в отрасль здравоохранения. Проведено структурирование деятельности семейного врача для дальнейшей реализации веб-, мобильно-ориентированной информационной системы в практике семейного врача, что является важным шагом для развития данного направления отрасли. Ведь именно это поможет структурировать работу врача, поддержать его в принятии решений и дать возможность для непрерывного профессионального развития.

Ключевые слова: семейная медицина, информационная система, алгоритм, мобильно-ориентированная среда. 
Вступ. Сьогодні втілення інформаційних технологій у практику сімейного лікаря $€$ необхідним кроком для повноцінного функціонування сімейної медицини [2]. Такий крок допоможе якісно проводити профілактику, діагностику, нагляд та значно покращить показники раннього виявлення захворювань. Особливо це стосується найбільш поширених захворювань людства, таких як серцево-судинні захворювання, цукровий діабет, онкологія тощо. Тільки в Україні дані захворювання $є$ причиною смерті в 63 \% випадків [1].

Сімейну медицину як спеціальність відрізняє ряд принципових особливостей. До них належать: довготривалість і безперервність спостереження, превентивність як основа діяльності сімейного лікаря, економічна ефективність та доцільність допомоги, координація медичної допомоги. Довготривалість допомоги включає в себе взаємовідносини сім'я лікар і лікар - вузькі спеціалісти, до яких приходиться звертатися по допомогу. В цьому випадку сімейний лікар проводить пацієнта через усі складності медичного сервісу, й це, звісно, потребує інформаційної підтримки.

Для повномірного здійснення своїх функцій сімейний лікар повинен володіти сучасними та прогресивними методами, що будуть доступними, iнформативними і полегшуватимуть роботу. До таких методів належить застосування мобільних додатків, веб-платформ для лікарів, що об'єднуватимуть інформацію про пацієнта, результати основних досліджень та відображатимуть алгоритм роботи сімейного лікаря. Такі програми є потужною підтримкою сімейного лікаря в прийнятті рішень.

Мета роботи: структуризація знань діяльності сімейного лікаря для подальшого включення в веб-, мобільно-орієнтовану інформаційну систему.

Матеріали та методи дослідження. Серед нормативних документів роботу сімейного лікаря регламентує наказ Міністерства охорони здоров’я України від 23.07.2001 № 303 «Про організацію роботи закладів (підрозділів) загальної практики - сімейної медицини» [4]. Відповідно до даного документу одними з основних завдань роботи сімейного лікаря $€$ :

- проведення комплексу профілактичних заходів із попередження захворювань, травм та отруєнь, зниження захворюваності, інвалідності та смертності серед прикріпленого населення;

- надання хворим кваліфікованої первинної лікувально-профілактичної допомоги в умовах амбулаторії та вдома;

- раннє виявлення захворювань, своєчасне амбулаторне обстеження і лікування хворих, за наявності показань забезпечення направлення хворих на консультування та госпіталізацію в інші лікувально-профілактичні заклади.

Інформатизація медицини стрімко розвивається, забезпечуючи лікарів можливістю якісніше надавати медичні послуги, навчатися, відслідковувати останні світові досягнення і, основне, надає підтримку в прийнятті рішень лікарем.

Результати та їх обговорення. Проведено структуризацію діяльності сімейного лікаря (рис. 1).

Отже, до основних напрямів діяльності сімейного лікаря пропонується ввести:

- превентивні заходи;

- ведення пацієнта;

- фахове вдосконалення;

- індивідуальне здоров’я лікаря.

Розглянемо їх детальніше.

Превентивні заходи. Структурну схему складових превентивних заходів подано на рис. 2.

Превентивний напрям $€$ основою діяльності сімейного лікаря. Лікар повинен здійснювати заходи, спрямовані на формування здорового способу життя. До них відносять індивідуальні консультації та

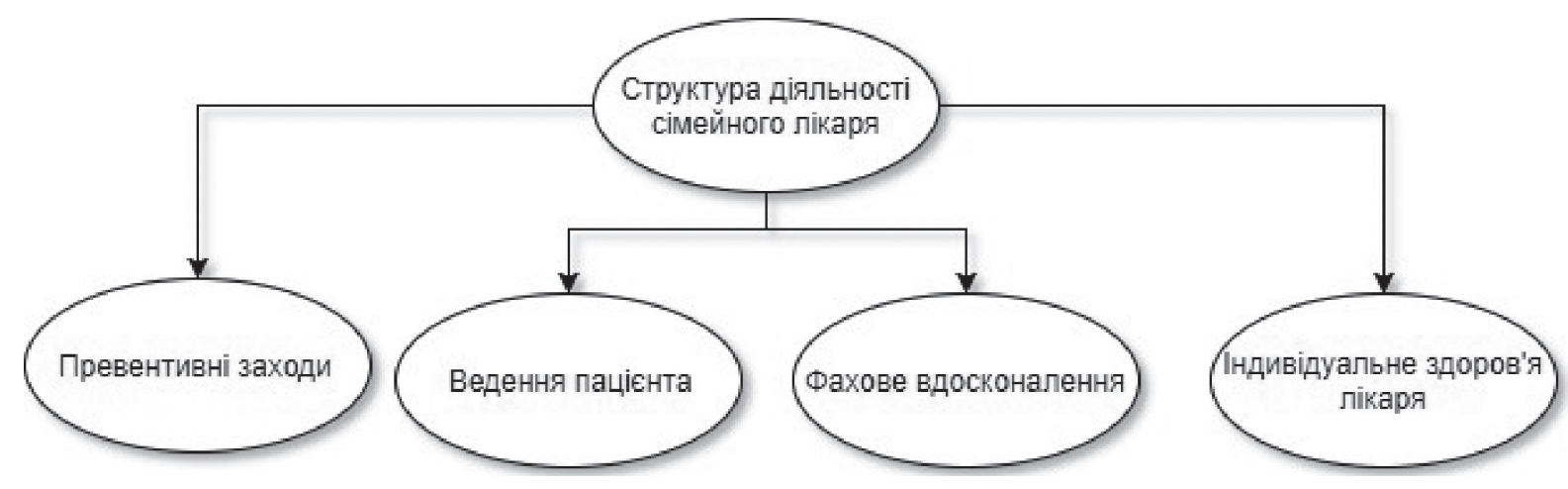

Рис. 1. Структурна схема напрямів діяльності сімейного лікаря 


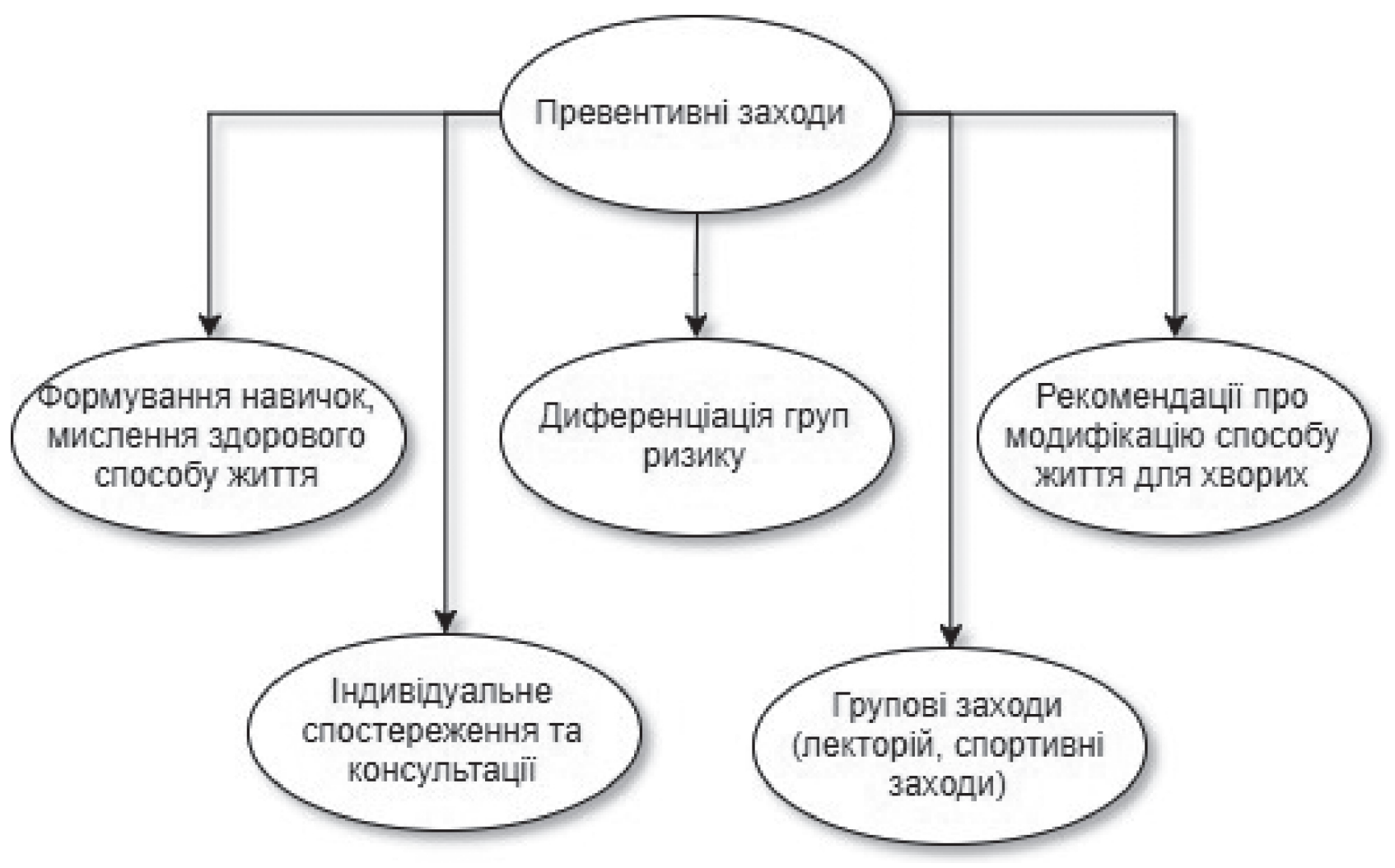

Рис. 2. Структурна схема складових превентивних заходів

проведення групових заходів. Лекторії $€$ потужним інструментом для роботи з пацієнтами дільниці. Тематично орієнтована робота $з$ пацієнтами забезпечує не тільки передавання інформації від сімейного лікаря до пацієнта, але й згуртування та модерацію за інтересами. На індивідуальних консультаціях лікар може визначати фактори ризику, допомагати в переході на здорове харчування та підтримувати в боротьбі зі шкідливими звичками. Диференціація груп ризику є ще одним інструментом у превентивних заходах. Визначаючи фактори ризику та об'єднуючи пацієнтів в групи, можна читати лекції та проводити групові консультації. Сімейний принцип роботи дає змогу забезпечити медичний нагляд за родиною, в якій є хворий, а також зосередитись на важко доступному лікареві контингенті молодого віку.

Ведення пацієнта. Структурну схему складових ведення пацієнта подано на рис. 3.

Ведення пацієнта починається з первинного прийому. Первинний прийом включає в себе знайомство з пацієнтом, збір анамнезу, огляд та основні обстеження. Після отримання даних пацієнта сімейний лікар повинен встановити попередній діагноз чи виділити основний синдром захворювання. За потреби пацієнт направляється на консультацію до вузьких спеціалістів або на додаткові обстеження. Після встановлення остаточного діагнозу призначається лікування. Лікування повинно включати як медикаментозні призначення, так і рекомендації з модифікації способу життя. В подальшому сімейний лікар веде спостереження даного пацієнта в динаміці. Велике значення надається тому, щоб запобігти розвитку інфекційних захворювань на дільниці. Тому при виявленні інфекційного захворювання лікар заповнює екстрене повідомлення та направляє його в санітарно-епідеміологічну станцію для проведення первинних заходів Також сімейний лікар приймає рішення щодо госпіталізації хворого. Приводом для госпіталізації може стати:

- неможливість встановити діагноз за допомогою засобів, що є в розпорядженні сімейного лікаря; - тяжкий стан або загроза погіршення стану хворого, необхідність інтенсивного лікування.

Фахове вдосконалення. Структурну схему напрямів фахового вдосконалення сімейного лікаря подано на рис. 4.

Для ефективної роботи сімейний лікар повинен здійснювати безперервний розвиток своїх знань. Участь у конференціях, курси з підвищення кваліфікації, здобуття нових навиків забезпечують ефективну роботу відповідно до сучасних нововведень. 


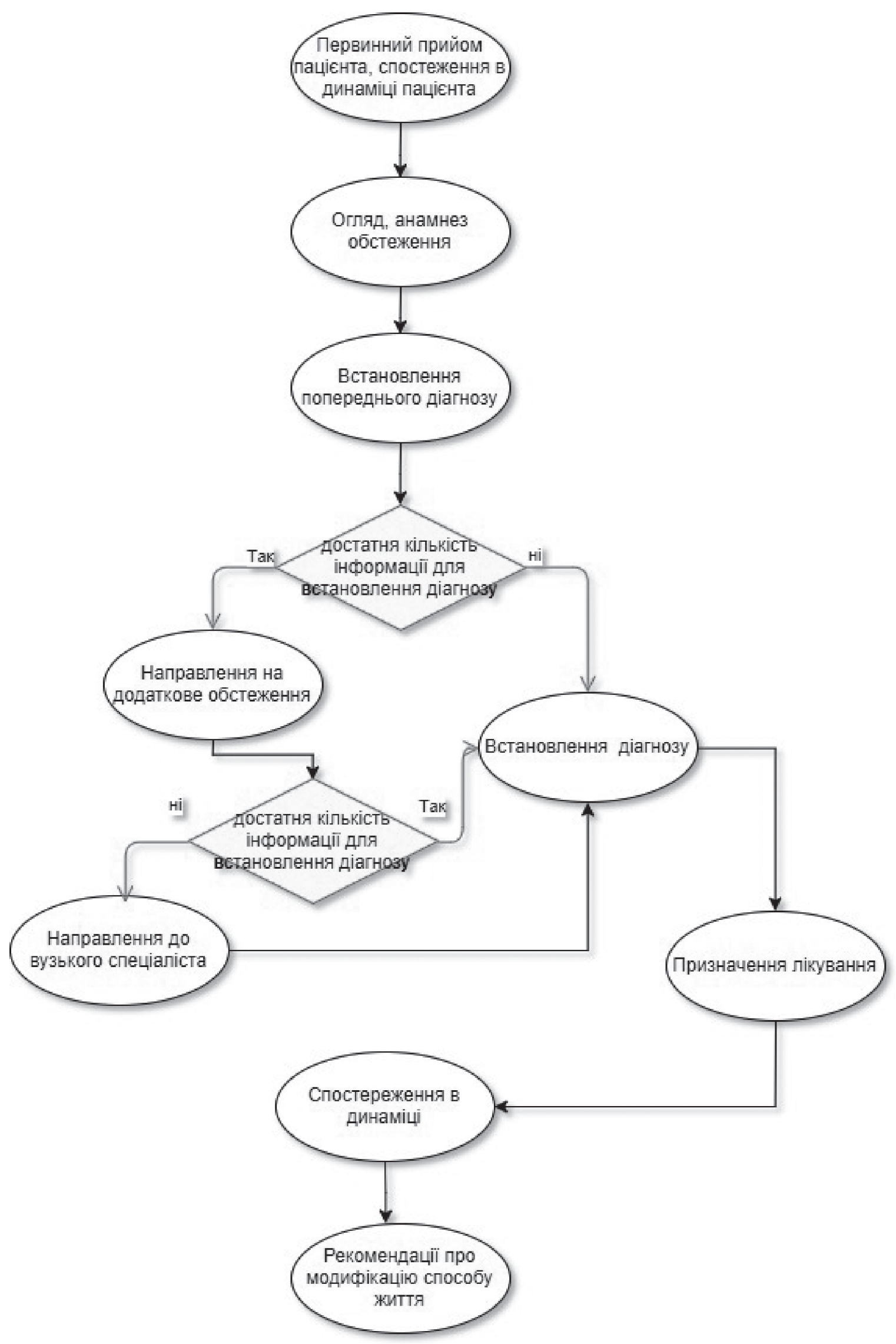

Рис. 3. Структурна схема складових ведення пацієнта 


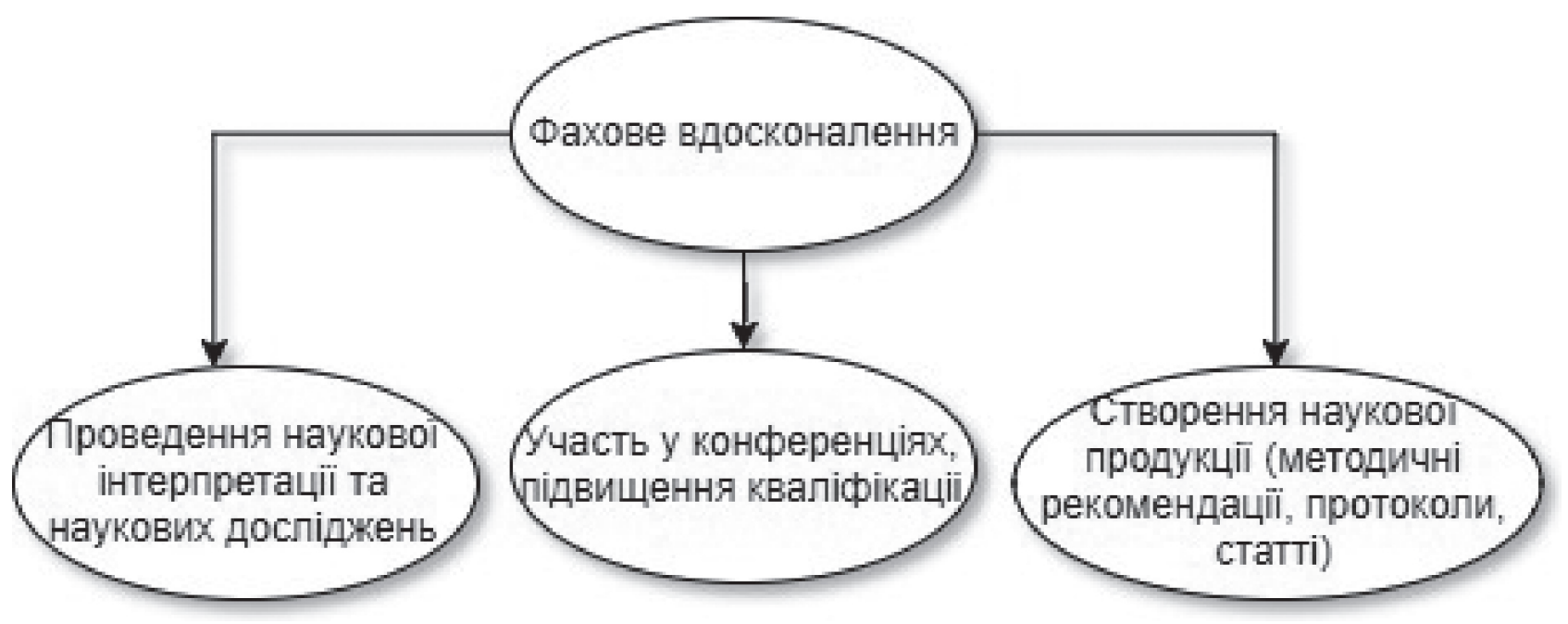

Рис. 4. Структурна схема напрямів фахового вдосконалення сімейного лікаря

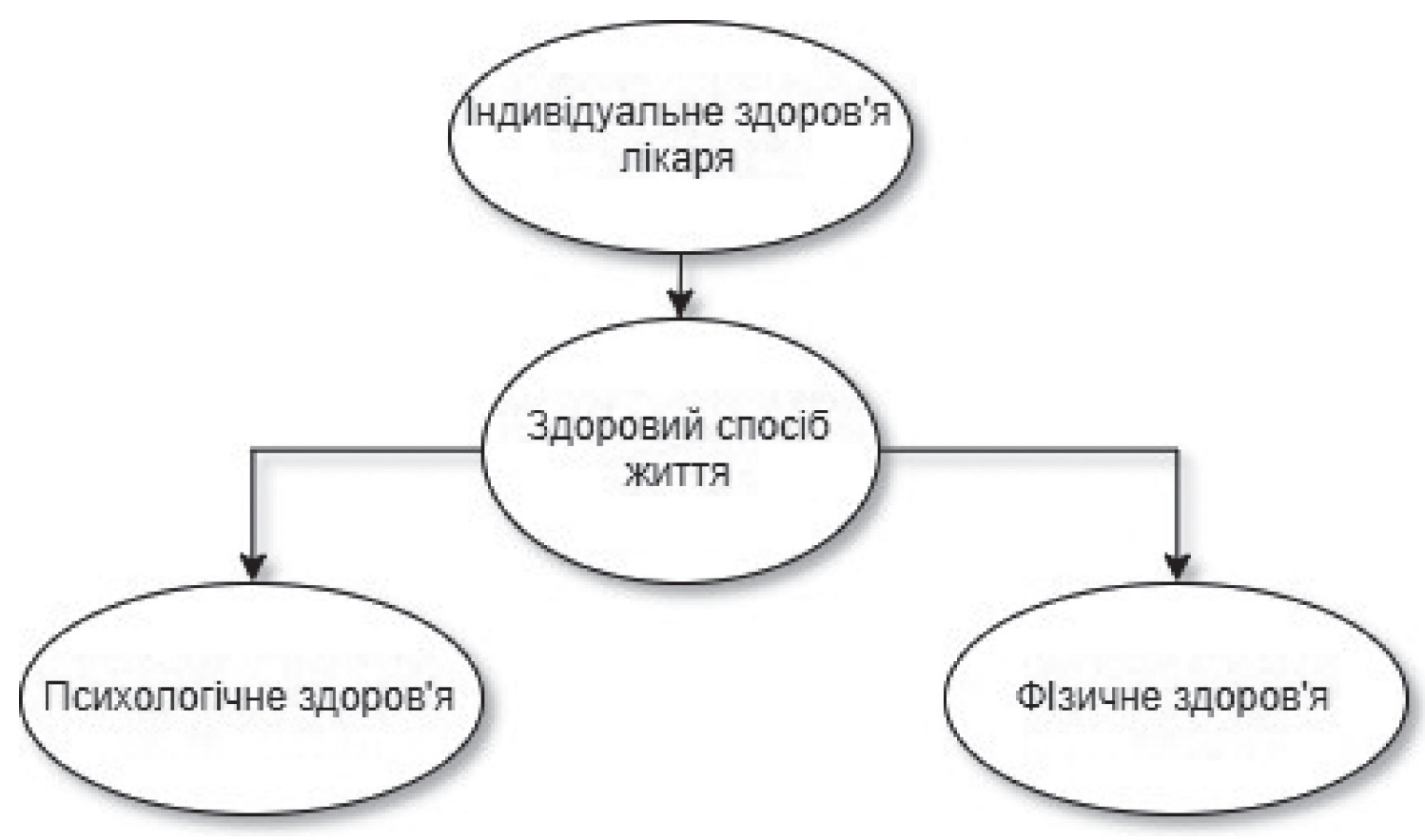

Рис. 5. Структурна схема напрямів формування та підтримання індивідуального здоров’я сімейного лікаря

Проведення наукової інтерпретації та наукових досліджень $є$ бажаними заходами в роботі сімейного лікаря. За результатами досліджень сімейний лікар повинен створювати наукову продукцію, до якої входять методичні рекомендації, протоколи, статті. Саме ініціативні лікарі допомагають розвивати даний напрям медицини.

Індивідуальне здоров’я лікаря. Структурну схему напрямів формування та підтримання індивідуального здоров’я сімейного лікаря подано на рис. 5.

Лікар повинен своїм способом життя, мисленням, жагою до знань демонструвати приклад здорового способу життя. Саме тому індивідуальне здоров’я лікаря є дуже важливою ланкою. Здорове харчування, фізичні вправи, відсутність шкідливих звичок і духовний розвиток - все це створює портрет людини, якій хочеться вірити та наслідувати. Бути прикладом і наставником - ось призначення сімейного лікаря.

Структуризація веб-, мобільно-орієнтованої інформаційної системи сімейного лікаря. Стрімкий розвиток різних напрямів інформаційних технологій забезпечує передумови до формування структури веб-, мобільно-орієнтованої інформаційної системи сімейного лікаря. Для забезпечення 


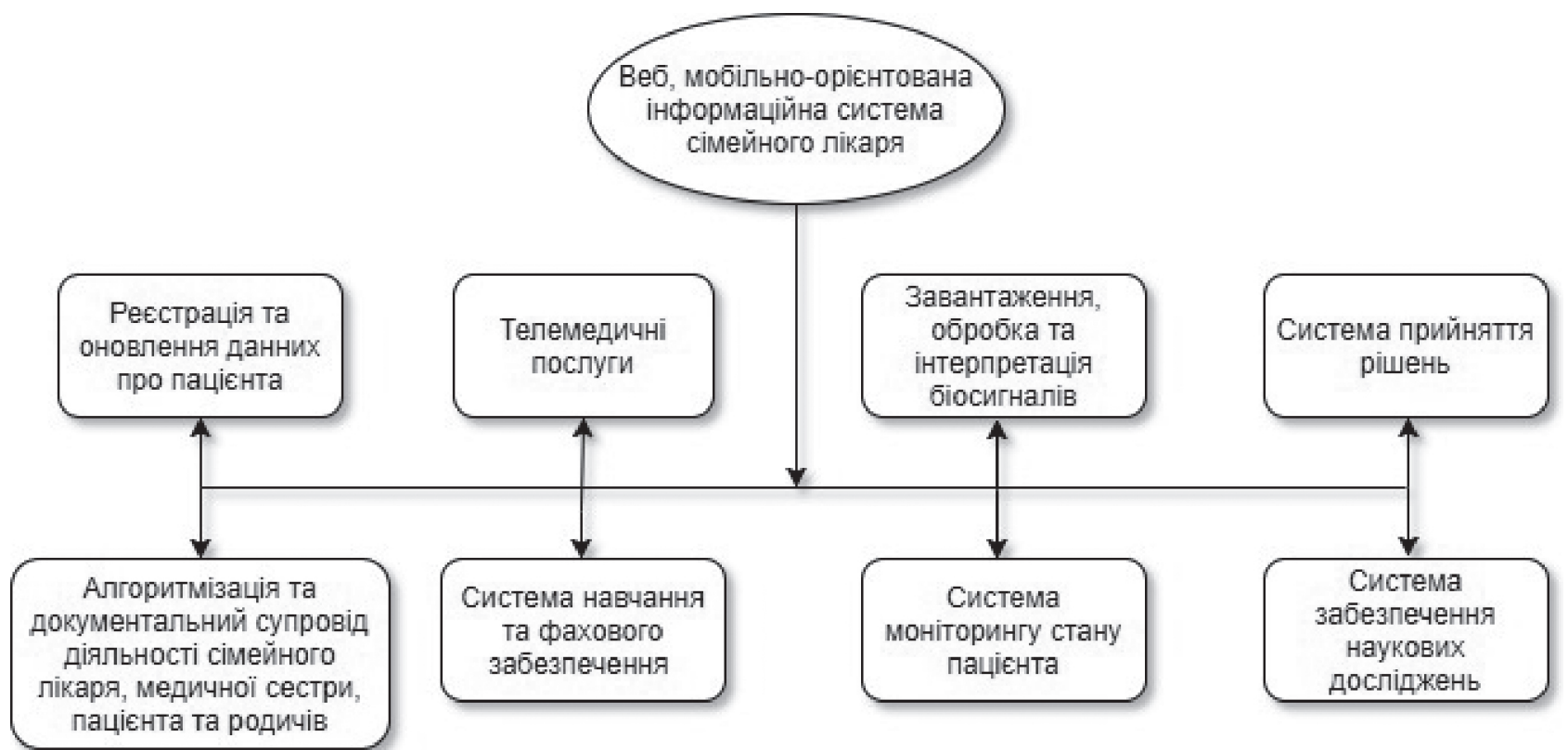

Рис. 6. Структурна схема веб-, мобільно-орієнтованої інформаційної системи сімейного лікаря

описаних вище видів діяльності сімейного лікаря пропонується використання таких компонентів інформаційної системи [3] (рис. 6).

Ключовими вимогами до веб-, мобільно-орієнтованої інформаційної системи сімейного лікаря $€$ зручність, ефективність та ресурсозбереження.

На жаль, наявне в галузі комп’ютерне обладнання та мобільні пристрої часто є морально та технічно застарілими, низько продуктивними. Тому розроблюване середовище має проводити основні операції на сервері (до прикладу Node. js - платформа 3 відкритим кодом для виконання високопродуктивних мережних додатків, написаних мовою JavaScript). Функції платформи не обмежені створенням серверних скриптів для веб, платформа може використовуватися й для створення звичайних клієнтських і серверних мережевих програм. Для забезпечення виконання JavaScript-коду використовується розроблений компанією Google рушій V8.

Пропонуєма веб-, мобільно-орієнтована інформаційна система сімейного лікаря включає в себе такі складові: реєстрація та оновлення даних про пацієнта, телемедичні послуги, завантаження, оброблення та інтерпретація біосигналів, система прийняття рішень. Деталізуємо зазначені складові.

Реєстрація та оновлення даних про пацієнта $€$ надзвичайно важливою опцією для практикуючого лікаря, що дозволяє значно зменшити кількість паперової документації та рутинної роботи. Всі дані про пацієнта повинні бути зібрані в одному місці, бути в постійному доступі та в зручному форматі. Це дасть змогу алгоритмізувати роботу лікаря, структурно оформити дані та мати чітку картину про стан здоров’я, фактори ризику та спрогнозувати можливі ускладнення в пацієнта.

Телемедичні послуги - дистанційні медичні консультації, консиліуми, контроль фізіологічних параметрів організму пацієнта, проведення діагностичних і лікувальних маніпуляцій, обмін результатами обстеження пацієнта, інші медичні послуги, а також медичні відеоконференції, відео семінари та відеолекції, що здійснюються у вигляді обміну електронними повідомленнями з використанням телекомунікацій. Такі послуги допомагають лікарю безперервно розвиватися та вдосконалювати знання, навіть у віддалених селах і в умовах постійної зайнятості.

Завантаження, оброблення та інтерпретація біосигналів - опція, що допомагає моніторувати стан пацієнта. Це дає змогу якісніше надавати медичні послуги, виключати так званий людський фактор та правильно розшифровувати біосигнали. Лікар буде мати змогу відслідковувати попередні біосигнали, порівнювати їх з наявними та тим самим слідкувати за станом здоров’я пацієнта.

Система прийняття рішень - система, що базується на засадах доказової медицини та діючих протоколах захворювань. Така система допоможе комплексно аналізувати дані пацієнта та на їх основі спрямовувати лікаря в його діях. 
Висновок. Структуризація діяльності та в подальшому реалізація веб-, мобільно-орієнтованої інформаційної системи в практиці сімейного лікаря $\epsilon$ важливим кроком для розвитку даного напряму галузі охорони здоров'я. Адже саме це допоможе структурувати роботу лікаря, підтримати його в прийнятті рішень та надати можливість для безперервного професійного розвитку.

\section{Література.}

1. Знаменська М. А. Аналіз захворюваності та поширеності хвороб серед населення України / М. А. Знаменська, Г. О. Слабкий // Неонатологія, хірургія та перинатальна медицина. — 2015. — № 3 (17). C. 24-29.

2. Мінцер О. П. Інформатика та охорона здоров’я / О. П. Мінцер // Медична інформатика та інженерія. — 2010. — № 2. — С. 8-21.

3. Вакуленко Д. В. Інформаційна система медичної (фізичної) реабілітації : дис. ... доктора біол. наук: 14.03.11 / Вакуленко Дмитро Вікторович. - К., 2015. - 514 c.

4. Про організацію роботи закладів (підрозділів) загальної практики - сімейної медицини : наказ МО3 України №: 303 від 23.07.2001 [Електронний ресурс] / Нормативно-директивні документи МОЗ України. — Режим доступу : http://mozdocs.kiev.ua/ view.php?id=1481.

\section{References.}

1. Znamenska, M. A., Slabkyi, H. O. (2015). Analiz zakhvoryuvanosti ta poshirenosti khvorob sered naselennya Ukraini [Analysis of the incidence and prevalence of diseases among the population of Ukraine]. Neonatologiya, khirurgiya ta perinatal'na meditsina (Neonatology, surgery and perinatal medicine), 3(17), 24-29 [In Ukrainian].

2. Mintser, O. P. (2010). Informatika ta okhorona zdorov'ya [Informatics and health care]. Medichna informatika ta inzheneriya (Medical Informatics and Engineering), 2, 8-21 [In Ukrainian].

3. Vakulenko, D. V. (2015). Informatsiina sistema medichnoï (fizichnoï) reabilitatsiï [Information system of medical (physical) rehabilitation] (Doctoral dissertation) [In Ukrainian].

4. Ministry of Health of Ukraine. (2001, July 23) Order No. 303: Pro organizatsiyu roboti zakladiv (pidrozdiliv) zagal'noi praktiki - simeinoi meditsini [On the organization of work of institutions (units) of general practice — family medicine]. Regulatory documents of the Ministry of Health of Ukraine. Retrieved from: http:// mozdocs.kiev.ua/view.php?id=1481 [In Ukrainian]. 